\title{
ANALISIS STRATEGI KOMUNIKASI PEMASARAN BIBIT IKAN (Studi Evaluasi Efektivitas Strategi Komunikasi Pemasaran Bibit Ikan Pada IBAP Lamongan)
}

\author{
*(Danu Kusbandono ${ }^{1}$, M. Yanto ${ }^{2}$ \\ Prodi Manajemen, Fakultas Ekonomi, Universitas Islam Lamongan \\ Jl. Veteran No.53A Lamongan \\ Telp. (0322 ) 324706, Faks. ( 0322 ) 324706 \\ Email:jpim@unisla.ac.id
}

\begin{abstract}
ABSTRAK
Benih ikan berkualitas baik dibutuhkan dalam tahapan utama pembesaran ikan. Peningkatan benih berkualitas mampu didapatkan dengan pengontrolan panti benih dan pakan benih. Benih berkualitas mampu dipenuhi dengan produksi benih secara intensif dan berkelanjutan. Ketersediaan pakan alami yang cukup merupakan salah satu faktor untuk mendapatkan hasil benih yang berkualitas. Pakan alami belum mampu digantikan oleh pakan buatan, sehingga kualitas dan kuantitas pakan alami menjadi faktor penentu kualitas benih ikan laut (Sumiarsa dan Irwan, 2010).

Di Lamongan banyak dijumpai penjual bibit ikan, mulai dari pedagang yang berada di rumah hingga penyedia jasa penjualan secara online. Salah satu penjualam online di Lamonganadalah IBAP(Instalasi Budidaya Air Payau)Lamongan. IBAP Lamongan ini merupakan situs jual benih ikan online,yang mempunyai beragam jenis dan berbagai macam variasi ukurannya untuk para petani ikan dan pembudidaya dengan memberikan harga terjangkau sesuai kebutuha.

Begitu banyak penjual bibit ikan yang ada di Lamongan, dimana srategi pemasaran antar kompetitor sangatlah berpengaruh. Dalam strategi komunikasi pemasaranIBAP Lamongan memfasilitasi pemasaran produknya. IBAP Lamonganmenggunakan alat promosi dalam strategi komunikasi pemasaran di masyarakat adalah program penyuluhan pada komunitas petani ikan di tingkat kabupaten maupun sekitar area Lamongan

Penelitian ini merupakan evaluasi keefektifan yang berniat untuk mengevaluasi apakah program yang dilaksanakan oleh IBAP Lamongan dalam upaya meningkatkan penjualan, loyalitas pelanggan, dan pemahaman konsumen di Kabupaten Lamongansudah efektif atau belum efektif. Penelitian ini menggunakan kerangka model CIPP (Context, Input, Process, Product), metode pengamatan, wawancara, dan dokumentasi. Langkah-langkah analisis penelitian ini adalah melalui pengumpulan data, penyajian data, reduksi data, dan penarikan kesimpulan.

Temuan dalam program penelitian ini berjalan dengan lancar karena dukungan pelanggan yang antusias, keterbatasan pemasaran dan infrastruktur untuk membuat program berjalan lambat. Harus ada alat promosi tambahan, sehingga pelanggan dan masyarakat umum akan menjadi tahu akan adanya IBAP Lamongan.
\end{abstract}

Kata kunci: Komunikasi Pemasaran, Strategi Komunikasi Pemasaran, Evaluasi Efektivitas, Analisis CIPP, Bibit Ikan.

Pendahuluan

Dalam sistem agribisnis

perikanan, dimana meliputi kegiatan

dimulai dari pengadaan sarana

produksi, produksi, pengolahan pasca panen (agroindustri), pemasaran dan kelembagaan adalah merupakan rangkaian kegiatan yang saling terkait satu sama lain. Semua kegiatan dalam agribisnis perikanan tersebut, terdapat 
proses menghasilkan produk. Produsen yang bergerak di bidang sarana produksi akan menghasilkan produk-produk pemenuhan kebutuhan untuk kegiatan produksi, dalam hal ini adalah produksi ikan untuk memenuhi kebutuhan pada kegiatan agroindustri. Khususnya kegiatan pemasaran (marketing), disaat produk sudah dihasilkan baik dalam kegiatan sarana produksi, produksi dan agroindustri, maka kegiatan pemasaran sangatlah penting.

Tanpa kegiatan pemasaran maka semua produk yang dihasilkan tersebut adalah merupakan seonggok barang yang tidak bermanfaat. Dengan demikian, kegiatan pemasaran adalah sangat penting dalam semua kegiatan yang menghasilkan barang ataupun jasa. Hasil perikanan dapat dikelompokkan ke dalam bahan mentah dan barang konsumsi. Sebagai bahan mentah dapat dibeli oleh pabrik atau usaha pengolahan untuk diolah menjadi barang jadi misalnya ikan kaleng, aneka olahan ikan, tepung ikan, dsb. Sebagai barang konsumsi akan dibeli oleh konsumen akhir (household consumer, restaurant, hospital, dll).

Para pelanggan IBAP Lamongan adalah mereka yang mempunyai kebutuhan akan bibit ikan. Untuk mempertahankan pelanggannya, IBAP
Lamongan pastinya melakukan berbagai cara dan strategi. Disisi lain, sangat dibutuhkan untuk mengevaluasi ke efektivitasan dari komunikasi pemasaran bibit ikan IBAP Lamongan tersebut. Agar mendapatkan hasil yang maksimal dalam melayani pelanggannya, maka diperlukan cara dan pendekatan komunikasi yang tepat.

IBAP (Instalasi Budidaya Air Payau) Lamongan merupakan unit produksi benih komoditas ikan air payau yang mempunyai standar jaminan mutu akan kualitas ikan baik bibit ikan maupun ikan ukuran medium (glondongan) dan bertanggung jawab atas ketersediaan benih (udang, nila, dll), dalam pemasaran IBAP Lamongan mempunyai program perencanaan untuk meningkatkan penjualan, diantaranya berupa penyuluhan pada kelompok petani ikan di sekitar area Lamongan,sosialisasi bibit ikan varian yang baru pada petani ikan dan melakukan peremajaan indukan yang dimiliki agar kualitas telur dan ketahanan terhadap penyakit menjadi lebih baik.

Dalam prakteknya tidak luput juga terdapat kendala-kendala dalam pelaksanaan program, permasalahan yang ditemukan pada IBAP Lamongan adalah melihat fenomena 
yang terjadi di kabupaten Lamongan ini, dimana sebuah organisasi yang bergerak di bidang penjualan bibit ikan dapat berkembang pesat dan lebih unggul dibandingkan industri-industri penjualan bibit ikan yang lain.

\section{Kajian Teori}

1. Komunikasi Interpersonal Menurut Judy C. Pearson dkk ( 2011 ), Komunikasi Interpersonal adalah proses yang menggunakan pesan-pesan untuk menggapai kesamaan makna antara-paling tidak-antara dua orang didalam sebuah suasana yang amat mungkin adanya kesempatan yang mirip bagi pembicara dan pendengar. Komunikasi interpersonal merupakan komunikasi antara dua orang atau lebih. Kegiatan tersebut sangat dominan dalam kegiatan seharihari yang dilakukan oleh individu satu dengan individu yang lain.

2. Komunikasi Organisasi

Manfaat komunikasi, memberi pengaruh positif bagi kemajuan perusahaan, memperbesar semangat kerja, menambah pengetahuan, mempermudah penyelesaian masalah, menyamakan persepsi, bertukar ide untuk kemajuan organisasi
(Kadar Nurzaman, 2014: 188)

3. Komunikasi Pemasaran

Komunikasi pemasaran adalah sarana yang digunakan perusahaan dalam upaya untuk menginformasikan, membujuk, dan mengingatkan konsumen secara langsung atau tidak langsung tentang produk dan merek yang mereka jual (Philip Kotler, 2007: 204).

a. Bauran Pemasaran

Pemasar sebaiknya memiliki pengetahuan dalam konsep dan prinsip pemasaran agar kegiatan pemasaran dapat tercapai sesuai dengan kebutuhan dan keinginan manusia, terutama pihak konsumen yang dituju (Agus Hermawan, 2012: 28).

Pemasaran bersandar pada konsep inti, yaitu (Freddy Rangkuti, 2009: 19-20):

1. Kebutuhan, keinginan, dan permintaan.

Kebutuhan adalah sesuatu yang diperlukan dan harus ada sehingga manusia akan berusaha memenuhi kebutuhannya. Keinginan adalah hasrat untuk memperoleh pemuas kebutuhan yang lebih spesifik akan kebutuhan yang mendalam. Permintaan adalah keinginan akan produk tertentu yang 
didukung oleh kemampuan dan kesediaan untuk membeli.

2. Produk atau jasa adalah segala sesuatu yang dapat ditawarkan untuk memuaskan suatu kebutuhan dan keinginan.

3. Nilai dan kepuasan, merupakan konsep penuntun dalam memilih produk mana yang dapat memuaskan dan mempunyai kapasitas berbeda sebagai perangkat tujuan.

4. Pertukaran dan transaksi merupakan cara-cara yang dilakukan orang dalam memperoleh produk yang diinginkannya.

5. Hubungan dan jaringan, merupakan strategi yang dilakukan pihak perusahaan dengan pihak-pihak kunci seperti pelanggan, pemasok, dan penyalur, guna mempertahankan referensi dan bisnis jangka panjang perusahaan.

6. Pasar, terdiri atas semua pelanggan potensial yang memiliki kebutuhan atau keinginan tertentu yang sama dan mampu melaksanakan pertukaran untuk memuaskan kebutuhan dan keinginan.

Enam model utama bauran komunikasi pemasaran: penjualan perorangan, iklan, promosi penjualan, pemasaran, publisitas, dan komunikasi di tempat pembelian (Terence A. Shimp, 2003: 5-6).

1. Penjualan perorangan (personal selling) adalah bentuk komunikasi yang dilakukan oleh tenaga penjual atau wiraniaga untuk menginformasikan dan membujuk kepada calon pembeli agar membeli produkatau jasa yang ditawarkan.

2. Iklan (advertising) adalah segala bentuk presentasi nonpribadi dan promosi gagasan, barang, atau jasa oleh sponsor tertentu yang harus dibayar (Philip Kotler, 2007: 244).

3. Promosi penjualan (sales promotion) adalah kegiatan pemasaran yang dilakukan oleh tenaga pemasar untuk merangsang dan mempengaruhi sikap pelanggan atau konsumen melakukan pembelian suatu produk dalam waktu yang singkat.

4. Pemasaran (marketing) adalah kegiatan dalam mempromosikan perusahaan dan merek mereka dengan mengasosiasikan perusahaan atau salah satu merek dengan kegiatan tertentu, seperti menjadi sponsor dalam suatu event kegiatan atau perlombaan.

5. Publisitas (publicity) 
berhubungan dengan komunikasi massa seperti iklan, tetapi juga tidak sepenuhnya seperti iklan. Publisitas berbentuk berita atau komentar editorial mengenai produk atau jasa dari perusahaan. Bentuk tersebut dimuat dalam media cetak dan televisi secara gratis karena perwakilan media menganggap berita tersebut layak disampaikan ke khalayak.

6. Komunikasi di tempat pembelian

$\begin{array}{lr}\text { (point of } & \text { purchase } \\ \text { communication) } & \text { adalah } \\ \text { komunikasi yang melibatkan alat } \\ \text { peraga seperti poster, } & \text { spanduk, } \\ \text { stiker, dan berbagai materi lain } & \text { untuk } \\ \text { yang didesain } & \text { keputusan } \\ \text { mempengaruhi } & \text { pembelian } \\ \text { membeli di tempat } & \text { didisplay } \\ \text { yang sudah } & \text { menarik } \\ \text { perusahaan guna } & \text { men } \\ \text { perhatian konsumen }\end{array}$

Tabel 1.1. Model Hierarki Tanggapan

\begin{tabular}{|c|c|}
\hline TAHAP & MODEL AIDA \\
\hline Tahap Kognitif & Perhatian \\
\hline Tahap Afektif & Minat \\
& \\
\hline Tahap Perilaku & Tindakan \\
\hline
\end{tabular}

Sumber: Philip Kotler dan Kevin Lane Keller, 2007

Dalam tanggapan komunikasi model mikro, terdapat 4 model hierarki tanggapan klasik yaitu model AIDA, model Hierarki Efek, model Inovasi Adopsi, dan model KomunikasiStrategi Komunikasi

Strategi komunikasi adalah kombinasi yang terbaik dari semua elemen komunikasi mulai dari komunikator, pesan, saluran (media), penerima sampai pada pengaruh (efek) untuk mencapai tujuan komunikasi yang optimal (Hafied Cangara, 2014: 64).

c. Strategi Pemasaran

Strategi pemasaran mengacu pada rencana perusahaan dalam menempatkan sumber dayanya dengan memposisikan produk atau jasa dan menargetkan kelompok konsumen spesifik 
guna mendapatkan keuntungan. Pengiklan, pemasar, dan sektor bisnis berkembang yang mendukung untuk menggunakan data besar guna memenuhi tujuan mereka sendiri (Nick dan Joseph, 2014: 1710).

Strategi pemasaran adalah suatu cara yang penting dilakukan oleh perusahaan dalam mencapai keuntungan. Strategi pemasaran adalah proses perencanaan perusahaan untuk mewujudkan tujuan perusahaan yang sesuai dengan visi perusahaan, persaingan merupakan motivasi utama dalam strategi pemasaran (Agus Hermawan, 2012: 40).

d. Evaluasi

Evaluasi adalah kegiatan yang berorientasi pada pengambilan keputusan, karena itu evaluasi harus membantu para pengambil keputusan dalam menetapkan keputusannya, misal untuk memperbaiki program dan memilih pendekatan yang lebih baik (Zaini Rohmad, 2014: 4142).

Stufflebeam mencoba menghubungkan evaluasi dengan pengambilan keputusan dalam penelitian evaluasi CIPP, dia membagi keputusan program menjadi 4 (empat) macam, yaitu (Zaini Rohmad, 2014: 82):

a. Context evaluation, to serve planning decision. Konteks evaluasi ini membantu merencanakan dalam keputusan, menentukan kebutuhan yang akan dicapai oleh program, dan merumuskan tujuan program.

b. Input evaluation, structuring decision. Evaluasi ini menolong mengatur keputusan, menentukan sumbersumber yang ada, alternatif apa yang diambil, apa rencana dan strategi untuk mencapai kebutuhan, bagaimana prosedur kerja untuk mencapainya.

c. Process evaluation, to serve implementing decision. Evaluasi proses untuk membantu mengimplementasikan keputusan. Sampai sejauh mana rencana yang ditetapkan telah dilaksanakan ? Apa yang harus direvisi ? Begitu pertanyaan tersebut terjawab, prosedur dapat dimonitor, dikontrol, dan diperbaiki.

d. Product evaluation, to serve recycling decision. Evaluasi produk untuk menolong atau untuk membantu dalam pengambilan keputusan selanjutnya. Apa hasil yang telah dicapai ? Apa yang dilakukan setelah 
program berjalan?

\section{Metodologi Penelitian}

Jenis penelitian yang digunakan dalam penelitian ini adalah penelitian evaluasi, yaitu penelitian yang mengkaji efektivitas (Sutopo, 2015: 15). Metode penelitian evaluasi digunakan untuk menggambarkan apa yang sebenarnya terjadi dan dampak apa yang terjadi dalam strategi komunikasi pemasaran IBAP Lamongan. Tujuan dari penelitian ini adalah ingin melihat hubungan dan ke efektivitasan dengan menganalisisnya.

Dalam penelitian ini menggunakan pendekatan kualitatif. Penelitian kualitatif merupakan prosedur penelitian yang menghasilkan data deskriptif berupa kata-kata tertulis atau lisan dari orang-orang (informan) atau perilaku yang diamati. Hal ini dikarenakan peneliti ingin menganalisis secara mendalam bagaimana komunikasi pemasaran produk yang terjadi pada IBAP Lamongan.

Lokasi penelitian ini adalah lingkup Kabupaten Sukoharjo. Dari kalangan pelanggan adalah yang tinggal di lingkup wilayah Lamongan. Pemilihan subyek penelitian ini menggunakan pemilihan sampel purposif atau purposive sampling. Merupakan pemilihan siapa subyek yang ada dalam posisi terbaik untuk memberikan informasi yang dibutuhkan, mereka dipilih karena dipercaya mewakili satu populasi tertentu (Ulber Silalahi, 2012: 272273). Subyek yang diteliti dalam penelitian ini adalah beberapa anggota organisasi IBAP Lamongan, seperti Pimpinan Perusahaan, Bendahara, Marketing, Pelanggan, dan Konsumen IBAP Lamongan. Subyek-subyek ini dipilih guna mengetahui dan mengevaluasi sistematika kerja serta komunikasi pemasaran yang dilakukan.

\section{Pembahasan}

Hasil Evaluasi Strategi Komunikasi Pemasaran Bibit Ikan

\begin{tabular}{|c|c|c|}
\hline DATA & HASIL & KETERANGAN/ANALISIS \\
\hline
\end{tabular}




\begin{tabular}{|c|c|c|}
\hline CONTEXT & $\begin{array}{l}\text { a. Latar Belakang Program } \\
\text { Latar belakang program untuk } \\
\text { meningkatkan penjualan, jumlah } \\
\text { pelanggan, dan konsumen IBAP } \\
\text { Lamongan. Selain itu untuk } \\
\text { membuat nama IBAP Lamongan } \\
\text { menjadi familiar di masyarakat. }\end{array}$ & $\begin{array}{l}\text { Latar belakang } \\
\text { dilaksanakannya program ini } \\
\text { untuk menjaga loyalitas } \\
\text { pelanggan, meningkatkan } \\
\text { penjualan, dan konsumen } \\
\text { IBAPLamongan ini sudah } \\
\text { sesuai dengan teori } \\
\text { komunikasi pemasaran dari } \\
\text { Philip Kotler, yaitu sarana } \\
\text { yang digunakan perusahaan } \\
\text { dalam upaya untuk }\end{array}$ \\
\hline
\end{tabular}




\begin{tabular}{|c|c|}
\hline $\begin{array}{l}\text {, blog, kunjungan dari sekolah } \\
\text { maupun instansi ke } \\
\text { IBAPLamongan, menerima siswa/i } \\
\text { atau mahasiswa/i magang atau yang } \\
\text { sedang melakukan riset penelitian. }\end{array}$ & $\begin{array}{l}\text { menginformasikan, } \\
\text { membujuk, dan } \\
\text { mengingatkan } \\
\text { konsumen secara } \\
\text { langsung atau tidak } \\
\text { langsung tentang } \\
\text { produk dan merek yang } \\
\text { mereka jual }\end{array}$ \\
\hline $\begin{array}{l}\text { b. Tujuan Program } \\
\text { Tujuan dilaksanakannya program } \\
\text { tersebut untuk meningkatkan } \\
\text { jumlah penjualan produk dan } \\
\text { informasi akan adanya } \\
\text { IBAPLamongan kepada } \\
\text { khalayak. }\end{array}$ & $\begin{array}{l}\text { Tujuan ini sesuai dengan } \\
\text { latar belakang program } \\
\text { sehingga kerjasama } \\
\text { antara pihak } \\
\text { IBAPLamongan dengan } \\
\text { pelanggan dapat saling } \\
\text { menguntungkan di kedua } \\
\text { belah pihak. }\end{array}$ \\
\hline $\begin{array}{l}\text { c. Sasaran Program } \\
\text { Sasarannya para pelanggan atau } \\
\text { pemilik usaha di area wilayah } \\
\text { Lamongan untuk mau bekerjasama } \\
\text { dengan pihak IBAPLamongandan } \\
\text { melakukan pembelanjaan berbagai } \\
\text { bibit ikanIBAPLamongan. } \\
\text { Sedangkan untuk program } \\
\text { penunjang lainnya, segmentasinya } \\
\text { menengah kebawah. }\end{array}$ & $\begin{array}{l}\text { Sasaran dari program } \\
\text { ini adalah pelanggan } \\
\text { yang mempunyai } \\
\text { usaha pembesaran } \\
\text { bibit ikan. Namun } \\
\text { belum difokuskan } \\
\text { yang menjadi target } \\
\text { sasarannya. }\end{array}$ \\
\hline $\begin{array}{l}\text { d. Perencanaan Program } \\
\text { Perencanaan program pada bulan } \\
\text { Agustus } 2018 \text { sampai batas waktu } \\
\text { yang tidak ditentukan karena pihak } \\
\text { IBAPLamonganingin } \\
\text { menginformasikan IBAP } \\
\text { Lamongankepada masyarakat. }\end{array}$ & $\begin{array}{l}\text { Strategi komunikasi } \\
\text { menurut Hafied } \\
\text { Cangara, yaitu } \\
\text { kombinasi yang terbaik } \\
\text { dari semua elemen } \\
\text { komunikasi mulai dari } \\
\text { komunikator, pesan, } \\
\text { saluran (media), } \\
\text { penerima sampai pada } \\
\text { pengaruh (efek) untuk } \\
\text { mencapai tujuan } \\
\text { komunikasi yang } \\
\text { optimal. Oleh karena } \\
\text { itu, tidak ada batasan } \\
\text { waktu dalam } \\
\text { pelaksanaan program. }\end{array}$ \\
\hline
\end{tabular}




\begin{tabular}{|l|l|l|}
\hline & $\begin{array}{l}\text { e. Kesesuaian Program dengan Visi dan } \\
\text { Misi }\end{array}$ & $\begin{array}{l}\text { Program bisa dikatakan } \\
\text { sesuai dengan visi dan } \\
\text { misi apabila konsumen } \\
\text { dan masyarakat luas } \\
\text { mengetahui tentang } \\
\text { IBAP LamonganJika dikaitkan dengan } \\
\text { visi dan misi, program ini sudah sesuai } \\
\text { meskipun belum sepenuhnya terlaksana } \\
\text { dengan baik. Perbaikan dilakukan pada } \\
\text { manajemen perusahaan agar lebih } \\
\text { terstruktur, dan memaksimalkan kinerja } \\
\text { masing-masing karyawan. }\end{array}$ \\
& $\begin{array}{l}\text { dari pihak internal } \\
\text { maupun pihak } \\
\text { eksternal perusahaan., } \\
\text { sehingga bisa } \\
\text { dirasakan manfaatnya } \\
\text { bagi pihak internal } \\
\text { maupun pihak } \\
\text { eksternal perusahaan. }\end{array}$ \\
\hline
\end{tabular}

\begin{tabular}{|c|c|c|}
\hline INPUT & $\begin{array}{l}\text { a. PelaksanaProgram } \\
\text { Pelaksana programnya dari pihak } \\
\text { IBAP Lamongan. Dalam } \\
\text { pelaksanaan program, bagian } \\
\text { marketingmempunyai peranan yang } \\
\text { cukup besar karena } \\
\text { bertanggungjawab atas berjalannya } \\
\text { program. Anggota struktural dari } \\
\text { IBAPLamonganjuga ikut membantu } \\
\text { kelancaran program. } \\
\text { - Tingkat pendidikan dari } \\
\text { pelaksana program cukup } \\
\text { memadai yaitu berpendidikan S1. } \\
\text { Sedangkan pembantu pelaksana } \\
\text { program berpendidikan S1 dan } \\
\text { D3. } \\
\text { - Pelaksana program tidak } \\
\text { ditentukan dari berapa lama masa } \\
\text { kerjanya, melainkan bagaimana } \\
\text { skill yang dimiliki masing-masing } \\
\text { individu. } \\
\text { - Pelatihannya dengan mengikuti } \\
\text { seminar-seminar danbimbingan } \\
\text { yang diberikan olehPemerintah } \\
\text { atau swasta. }\end{array}$ & $\begin{array}{l}\text { Cara kerja pelaksana program } \\
\text { dalam IBAP Lamonganini } \\
\text { sesuai dengan teori menurut } \\
\text { Kadar Nurzaman, yaitu } \\
\text { manfaat komunikasi } \\
\text { organisasi, memberi } \\
\text { pengaruh positif bagi } \\
\text { kemajuan perusahaan, } \\
\text { memperbesar semangat kerja, } \\
\text { menambah pengetahuan, } \\
\text { mempermudah penyelesaian } \\
\text { masalah, menyamakan } \\
\text { persepsi, bertukar ide untuk } \\
\text { kemajuanorganisasi. }\end{array}$ \\
\hline
\end{tabular}




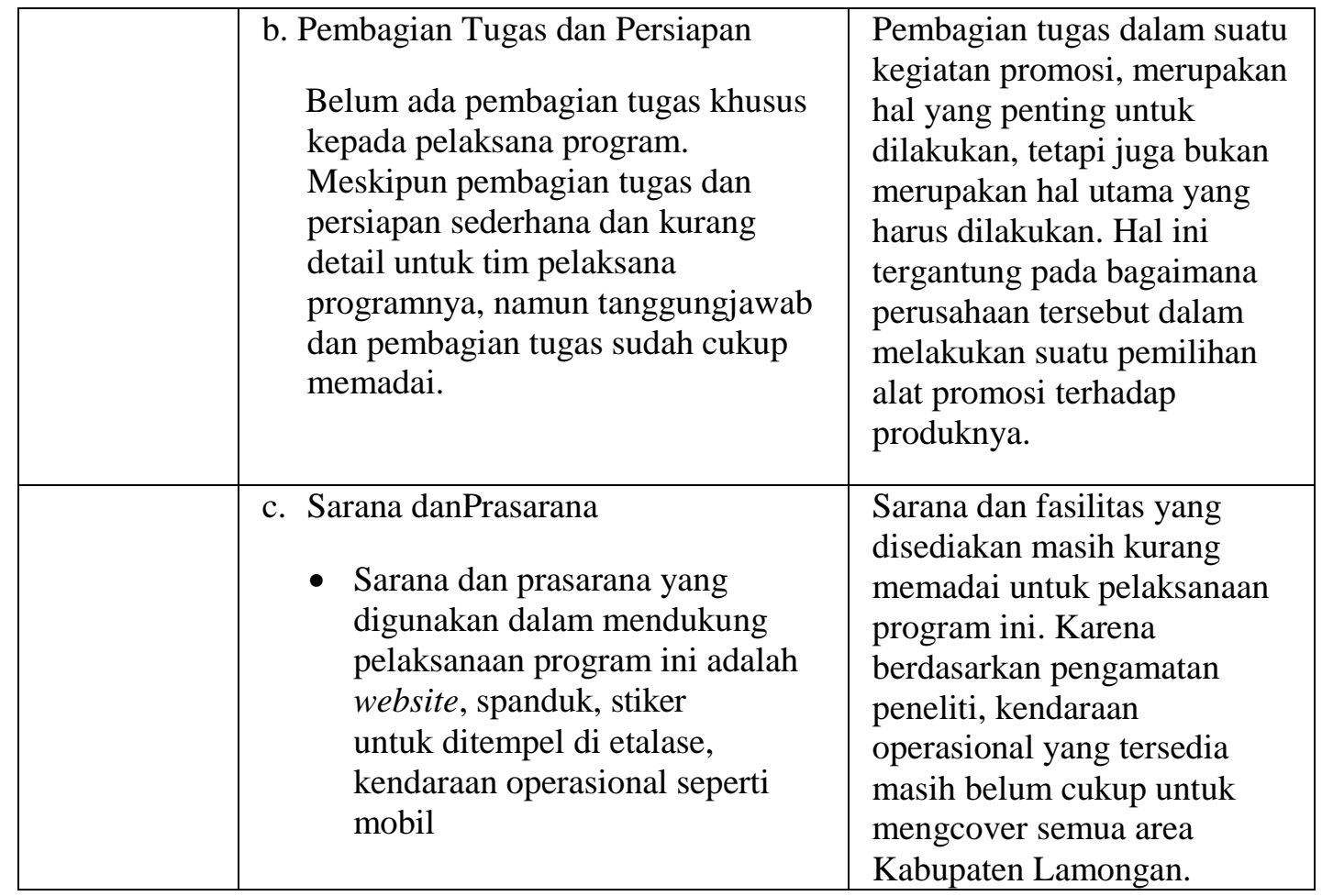

\begin{tabular}{|l|l|l|}
\hline dan motor. & $\begin{array}{l}\text { Hal ini akan memperlambat } \\
\text { penyebaran informasi dan } \\
\text { promosi di wilayah } \\
\text { Lamongan. }\end{array}$ \\
& $\begin{array}{l}\text { Alokasi anggaran dana yang } \\
\text { dikeluarkan setiap bulannya } \\
\text { untuk program ini sebesar Rp } \\
5.500 .000,-.\end{array}$ & \\
& $\begin{array}{l}\text { Penyediaan sarana dan prasarana } \\
\text { serta dana dari alokasi anggaran yang } \\
\text { telah disediakan dari IBAP } \\
\text { Lamongandinilai kurang memadai } \\
\text { untuk mencapai hasil yang } \\
\text { maksimal. }\end{array}$ & \\
\hline
\end{tabular}




\begin{tabular}{|c|c|c|}
\hline \multirow[t]{4}{*}{ PROCESS } & $\begin{array}{l}\text { a. Bentuk Kegiatan } \\
\text { Bentuk kegiatan dibedakan menjadi } \\
\text { dua yaitu dengan komunikasi } \\
\text { langsung dan komunikasi tidak } \\
\text { langsung. Komunikasi langsung } \\
\text { berupa komunikasi secara tatap } \\
\text { muka dengan bertemu secara } \\
\text { langsung antara pihak } \\
\text { IBAPLamongan dengan pelanggan. } \\
\text { Komunikasi tidak langsung } \\
\text { menggunakan fasilitas dari media } \\
\text { eksternal, seperti lewat media } \\
\text { website, e-commerce, , stiker } \\
\text { branding, blog, event, sponsorship, } \\
\text { seminar, kunjungan dari instansi, } \\
\text { dan publisitas. }\end{array}$ & $\begin{array}{l}\text { Media eksternal berupa } \\
\text { media lini bawah yang } \\
\text { digunakan sebagai alat } \\
\text { promosi tersebut dipilih } \\
\text { dengan pertimbangan } \\
\text { anggaran dana yang } \\
\text { disediakan untuk } \\
\text { kegiatan komunikasi } \\
\text { pemasaran. } \\
\text { Komunikasi langsung } \\
\text { dengan tatap muka, efektif } \\
\text { mengajak secara persuasif } \\
\text { kepada pelanggan untuk } \\
\text { bersedia mengikuti } \\
\text { program tersebut. }\end{array}$ \\
\hline & $\begin{array}{l}\text { b. Fokus Kegiatan } \\
\text { Fokus kegiatan adalah dengan } \\
\text { komunikasi secara langsung. } \\
\text { Berdasarkan pengamatan peneliti, } \\
\text { komunikasi secara langsung dinilai } \\
\text { lebih efektif dalam meyakinkan dan } \\
\text { menarik calon pelanggan dan } \\
\text { konsumen. }\end{array}$ & $\begin{array}{l}\text { Fokus kegiatan tersebut } \\
\text { sesuai dengan buku dari } \\
\text { Onong Uchjana Effendy, } \\
\text { yaitu proses pengiriman } \\
\text { dan penerimaan pesan- } \\
\text { pesan antara dua orang, } \\
\text { atau diantara sekelompok } \\
\text { kecil orang-orang dengan } \\
\text { umpan balik seketika. }\end{array}$ \\
\hline & $\begin{array}{l}\text { c. Kelancaran Pelaksanaan Program } \\
\text { Pelaksanaan program komunikasi } \\
\text { pemasaran kepada pelanggan } \\
\text { IBAPLamonganberjalan lancar. Hal } \\
\text { ini karena dukungan dan antusiasme } \\
\text { dari pelanggan. }\end{array}$ & $\begin{array}{l}\text { Pelanggan bersedia } \\
\text { bekerjasama untuk } \\
\text { membangun hubungan } \\
\text { mitra bisnis dengan } \\
\text { pihak IBAP Lamongan. }\end{array}$ \\
\hline & $\begin{array}{l}\text { d. Strategi } \\
\text { - Strategi yang dilakukandengan }\end{array}$ & $\begin{array}{l}\text { Strategi yang dipakai IBAP } \\
\text { Lamongan dengan }\end{array}$ \\
\hline
\end{tabular}




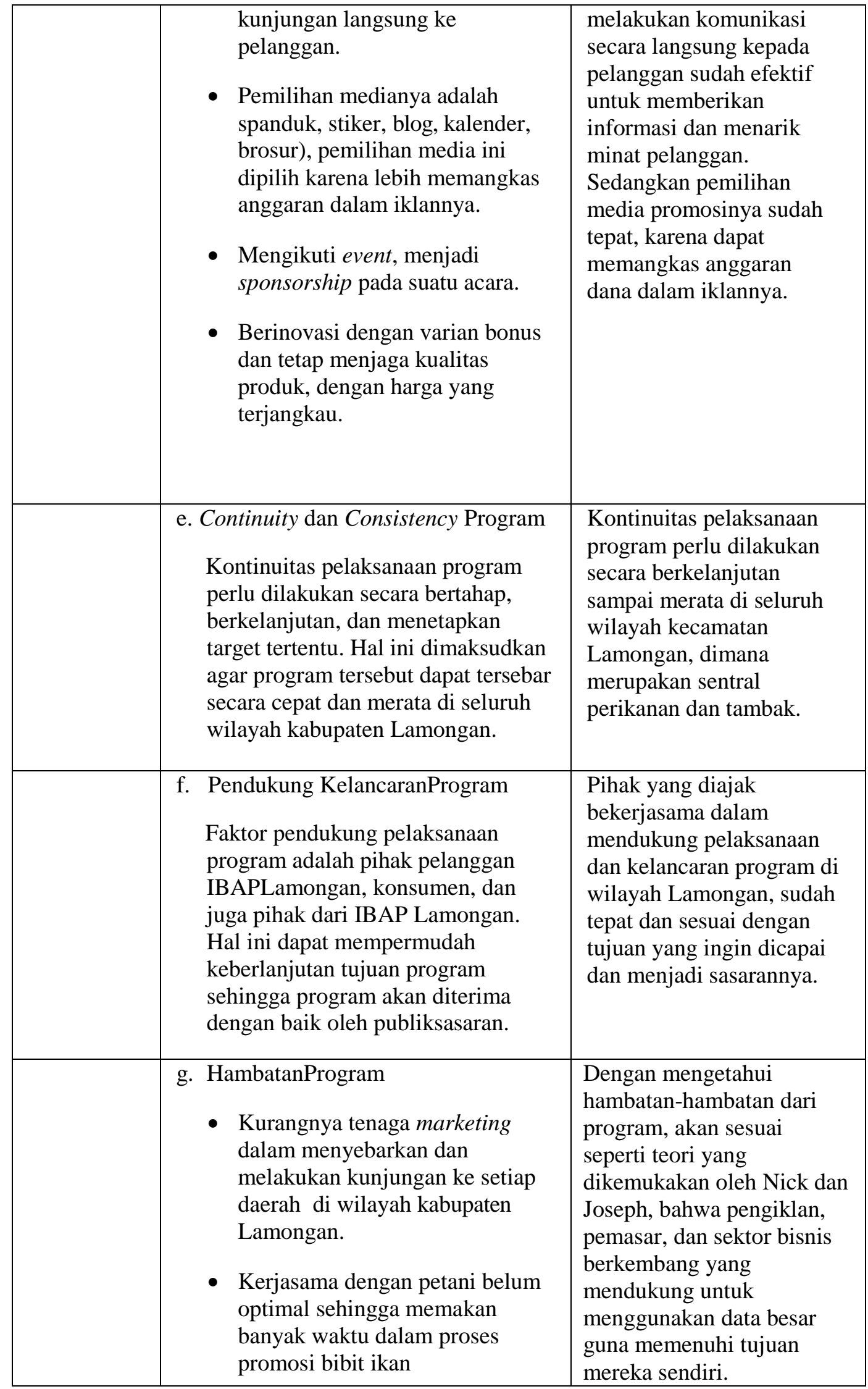




\begin{tabular}{|c|c|c|}
\hline & $\begin{array}{l}\text { - Logistik ketersediaan suplai bibit } \\
\text { yang kadang tidak bisa } \\
\text { diprediksi ketersediaan dan } \\
\text { kualitasnya. } \\
\text { - Sikap masyarakat dan konsumen } \\
\text { bibit ikan yang tidak } \\
\text { memperhatikan adanya media } \\
\text { komunikasi pemasaran yang } \\
\text { dilakukan oleh IBAPLamongan. } \\
\text { - Kurangnya kendaraan } \\
\text { operasional, sehingga } \\
\text { menghambat pergerakan } \\
\text { pelaksanaanprogram. } \\
\text { Kinerja pelaksana program yang } \\
\text { kurang maksimal danterstruktur } \\
\text { denganbaik. }\end{array}$ & \\
\hline PRODUCT & $\begin{array}{l}\text { a. Pencapaian Tujuan } \\
\text { Perbaikan mulai dari tenaga } \\
\text { marketing yang memadai, prasarana, } \\
\text { pengetahuan pihak pelanggan akan } \\
\text { program yang dilaksanakan dan } \\
\text { product knowledge, menambah alat } \\
\text { promosi pemasaran, dan } \\
\text { kerjasamanya dalam menarik } \\
\text { konsumen untuk membeli bibit ikan } \\
\text { diIBAPLamongan, agar pencapaian } \\
\text { tujuan program dapat terealisasi. } \\
\text { Karena masih banyak yang belum } \\
\text { mengetahui adanya penjualan } \\
\text { bibit ikan di Lamongan. }\end{array}$ & $\begin{array}{l}\text { Setiap perusahaan dituntut } \\
\text { melakukan evaluasi pada setiap } \\
\text { programnya. Hal ini sesuai } \\
\text { dengan yang dikemukakan } \\
\text { Zaini Rohmad, bahwa evaluasi } \\
\text { adalah kegiatan yang } \\
\text { berorientasi pada pengambilan } \\
\text { keputusan, karena itu evaluasi } \\
\text { harus membantu para } \\
\text { pengambil keputusan dalam } \\
\text { menetapkan keputusannya, } \\
\text { misal untuk memperbaiki } \\
\text { program dan memilih } \\
\text { pendekatan yang lebih baik. }\end{array}$ \\
\hline & $\begin{array}{l}\text { b. Parameter Keberhasilan } \\
\text { Program ini akan membantu } \\
\text { penjualan IBAPLamongandi } \\
\text { Lamongan, karena merupakan model } \\
\text { program bisnis ke bisnis. Sehingga } \\
\text { berdampak pada jumlah peningkatan } \\
\text { permintaan bibit ikan pada IBAP } \\
\text { Lamongan. }\end{array}$ & $\begin{array}{l}\text { Hal ini sesuai dengan yang } \\
\text { dikemukakan oleh Freddy } \\
\text { Rangkuti, bahwa pasar terdiri } \\
\text { atas semua pelanggan potensial } \\
\text { yang memiliki kebutuhan atau } \\
\text { keinginan tertentu yang sama } \\
\text { dan mampu melaksanakan } \\
\text { pertukaran untuk memuaskan } \\
\text { kebutuhan }\end{array}$ \\
\hline
\end{tabular}




\begin{tabular}{|c|c|c|}
\hline & & dan keinginan. \\
\hline & $\begin{array}{l}\text { c. Harapan Pelanggan atau Publik } \\
\text { Sasaran dan Ahli } \\
\text { - Pelanggan atau partnership } \\
\text { berharap, kualitas bibit ikan dan } \\
\text { harga ditingkatkan agar kualitas } \\
\text { bibit ikan tersebut lebih baik } \\
\text { dan lebih tahan terhadap } \\
\text { penyakit. } \\
\text { - Menurut konsumen, konsumen } \\
\text { yang sudah biasa membeli bibit } \\
\text { ikan di IBAP Lamongan, } \\
\text { biasanya engggan beralih dengan } \\
\text { penjual bibit ikan yang lain } \\
\text { karena ketakutan akan kualitas } \\
\text { bibit yang di jual. }\end{array}$ & $\begin{array}{l}\text { Dengan adanya masukan dan } \\
\text { saran dari pelanggan IBAP } \\
\text { Lamongan, maka dapat } \\
\text { dijadikan sebagai referensi } \\
\text { dan evaluasi untuk melakukan } \\
\text { perbaikan- perbaikan kegiatan } \\
\text { program sehingga ke } \\
\text { depannya akan dapat } \\
\text { terlaksana dengan lebih baik } \\
\text { lagi. }\end{array}$ \\
\hline$D A M P A K$ & $\begin{array}{l}\text { a. Internal Positif } \\
\text { Program tersebut bisa menjadi } \\
\text { jembatan antara pelanggan dengan } \\
\text { pihak IBAPLamonganuntuk } \\
\text { bekerjasama dalam memperkenalkan } \\
\text { bibit ikanIBAP Lamongankepada } \\
\text { konsumen dan masyarakat luas. } \\
\text { b. Internal Negatif } \\
\text { Pemerataan promosi yang dilakukan } \\
\text { IBAPLamonganmasih kurang } \\
\text { maksimal, masih banyak konsumen } \\
\text { yang belum tahu macam-macam } \\
\text { bibit ikan yang ada di IBAP } \\
\text { Lamongan. } \\
\text { c. Eksternal Positif } \\
\text { Walaupun program tergolong baru, } \\
\text { ada beberapa konsumen yang sudah } \\
\text { mengetahui IBAP Lamongan } \\
\text { melalui media promosi yang lain, } \\
\text { yang juga dilakukan oleh IBAP } \\
\text { Lamonganuntuk menunjang } \\
\text { program yang sedang gencar } \\
\text { dilakukannya saat ini. }\end{array}$ & $\begin{array}{l}\text { a. Internal Positif } \\
\text { Ini sesuai dengan teori dari } \\
\text { Terence A. Shimp, yaitu } \\
\text { promosi penjualan (sales } \\
\text { promotion) adalah kegiatan } \\
\text { pemasaran yang dilakukan } \\
\text { oleh tenaga pemasar untuk } \\
\text { merangsang dan } \\
\text { mempengaruhi sikap } \\
\text { pelanggan atau konsumen } \\
\text { melakukan pembelian } \\
\text { suatu produk dalam waktu } \\
\text { yangsingkat. } \\
\text { b. Internal Negatif } \\
\text { Kesiapan SDM terhadap } \\
\text { adanya suatu program baru } \\
\text { sangat berpengaruh } \\
\text { terhadap kinerja } \\
\text { perusahaan secara } \\
\text { keseluruhan karena hal ini } \\
\text { akan berdampak pada } \\
\text { loyalitas dan kepuasan } \\
\text { pelanggan sebagai pihak }\end{array}$ \\
\hline
\end{tabular}




\begin{tabular}{|c|c|}
\hline $\begin{array}{l}\text { d. Eksternal Negatif } \\
\text { - Dampakkognitif } \\
\text { Masyarakat khususnya konsumen } \\
\text { bibit ikan masih ada yang belum } \\
\text { mengetahui tentang adanya } \\
\text { bibityang berkualitas yang ada } \\
\text { diIBAP Lamongan. } \\
\text { Dengan demikian, dampak } \\
\text { kognitif ini belum sepenuhnya } \\
\text { berhasil dengan baik. } \\
\text { - Dampakafektif } \\
\text { Konsumen masih ada yang tidak } \\
\text { menanyakan tentang produk } \\
\text { IBAP Lamongan. Mereka tidak } \\
\text { begitu peduli dengan display } \\
\text { promosi yangada. } \\
\text { - Dampakbehavioral } \\
\text { Pelanggan sangat antusias dengan } \\
\text { program yang ditawarkan oleh } \\
\text { IBAP Lamongan dan juga } \\
\text { peningkatan permintaan bibit } \\
\text { ikan di IBAP Lamongan. }\end{array}$ & $\begin{array}{l}\text { yang menjadi sasaran } \\
\text { program agar percaya } \\
\text { untuk bekerjasama dengan } \\
\text { IBAP Lamongan. } \\
\text { c. } \text { Eksternal Positif } \\
\text { Dari data yang disajikan } \\
\text { dapat diketahui bahwa } \\
\text { program sudah berjalan } \\
\text { sesuai rencana dan tujuan } \\
\text { dari program. Namun } \\
\text { masih kurangoptimal. } \\
\text { d. EksternalNegatif } \\
\text { Sesuai yang dikemukan } \\
\text { oleh Agus Hermawan, } \\
\text { bahwa pemasar sebaiknya } \\
\text { memiliki pengetahuan } \\
\text { dalam konsep dan prinsip } \\
\text { pemasaran agar kegiatan } \\
\text { pemasaran dapat tercapai } \\
\text { sesuai dengan kebutuhan } \\
\text { dan keinginan manusia, } \\
\text { terutama pihak konsumen } \\
\text { yang dituju. }\end{array}$ \\
\hline
\end{tabular}

\section{Penutup}

\section{Kesimpulan}

Berdasarkan hasil
penelitian dan evaluasi yang
dilakukan oleh peneliti terhadap
strategi komunikasi pemasaran
yang dilakukan oleh industri

kecil, yaitu IBAP Lamongan

terkait alat promosi penjualan

yang digunakannya, apakah

berjalan dengan efektif atau

tidak. Peneliti menemukan

beberapa kekurangan dan kendala dalam pelaksanaan

program, sehingga program

berjalan kurang optimal dan

kurang efektif, juga keterbatasan

data yang diberikan oleh pihak

IBAP Lamongan kepada peneliti.

\section{Saran}

1. Bagi IBAP Lamongan

a. Penambahan tenaga

personil marketing dalam 
program pemasarannya

sebaiknya

segeradilakukan.

b. Sebaiknya membentuk tim khusus pelaksana program, agar alur kegiatan program berjalan rapi sesuai bidangnya masingmasing dan tidak bercampur dengan anggota karyawan yang lain atau double job, merangkap dua pekerjaan dan dua tanggungjawab dalam kegiatan di IBAP Lamongan.

c. Prasarana berupa motor dan mobil sebaiknya ditambah lagi agar program dapat berjalanlancar.

d. IBAP Lamongan sebaiknya memanfaatkan media lain, seperti memasang alat promosi berupa banner atau spanduk pada tempattempat strategis atau di pinggir jalan, menggunakan media elektronik lokal seperti iklan radio.

e. Sebaiknya selalu memberikan pengarahan kepada marketing lama dan marketing baru untuk selalu menjaga intensitas komunikasinya dengan para pelanggan. Sehingga pelanggan menjadi loyal untuk bekerjasama dengan IBAP Lamongan.

f. IBAP Lamongan sebaiknya tidak menutup informaasi mengenai produk kompetitor, seperti menduplikasi apa yang dilakukan oleh IBAP Lamongan. Selain itu, alangkah lebih baik apabilamenetapkan

kompetitor khusus sebagai acuan untuk berkembang lebih baik dari kompetitortersebut.

2. Bagi Pelanggan danKonsumen

a. Pelanggan bersedia berpartisipasi dalam program yang dilaksanakan oleh IBAP Lamongan, sehingga akan 
memudahkan penjualan

bibit ikan di IBAP

Lamongan.

b. Konsumen

dan

masyarakat luas peduli

dan tanggap terhadap

model komunikasi

pemasaran yang

dilakukan oleh IBAP

Lamongan.

3. Bagi PenelitiLain

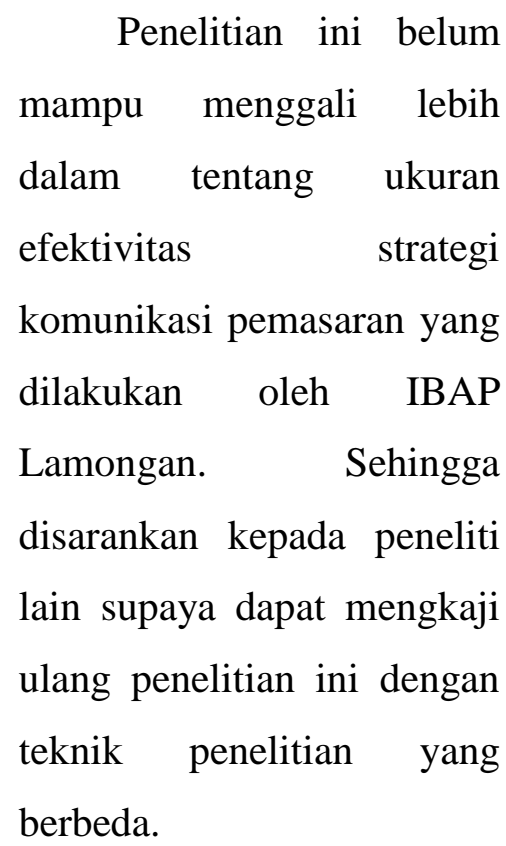

\section{Daftar Pustaka}

Cangara, Hafied. (2014). Perencanaan dan Strategi Komunikasi. Jakarta: PT. RajaGrafindo Persada

Couldry, Nick, Joseph Turow. (2014). "Advertising, Big Data, and the Clearance of the Public Realm: Marketers' New Approaches to the Content Subsidy", International Journal of Communication Vol 8. Page 1710-1723. London School of Economics, UK; University of Pennsylvania, USA

Effendy, Onong Uchjana. (2003). Ilmu, Teori, dan Filsafat Komunikasi. Bandung: PT. Citra Aditya Bhakti Hermawan, Agus. (2012). Komunikasi Pemasaran. Jakarta: Penerbit Erlangga Kotler, Philip, KevinLane Keller.(2007). Manajemen Pemasaran(Edisi Alih

Bahasa Indonesia); Edisi 12 Jilid 2. Jakarta: PT. Indeks

Nurzaman, Kadar. (2014). Manajemen Perusahaan. Bandung: CV. Pustaka Setia Rangkuti, Freddy. (2009). Strategi Promosi yang Kreatif dan Analisis Kasus

Integrated Marketing Communication. Jakarta: PT. Gramedia Pustaka Utama

Rohmad, Zaini. (2014). Evaluasi Kinerja; Suatu Pengantar. Surakarta: UPT UNS Press

Shimp, Terence A. (2003). Periklanan Promosi dan Aspek Tambahan Komunikasi Pemasaran Terpadu (Edisi Alih Bahasa Indonesia); Edisi ke-5 Jilid 1. Jakarta: Penerbit Erlangga

Silalahi, Ulber. (2012). Metode Penelitian Sosial. Bandung: PT. Refika Aditama Sutopo, dkk. (2015). Peranan Komunikasi Terhadap Perubahan Sosial. Surakarta: UPT UNS Press 